Kronikk | Presidentvalgkampen

\title{
Samhandling den ny vin eller keiserens nye klær?
}

\author{
En ukritisk oppbygging av nye og fragmenterte tjenester i kommune- \\ helsetjenesten uten å prioritere god tilgjengelighet til medisinsk \\ behandling av høy kvalitet, vil ikke styrke samhandling og tjene folke- \\ helsen, men føre til enda sterkere press på spesialisthelsetjenesten.
}

\section{Jan Emil Kristoffersen}

jan.emil.kristoffersen@legeforeningen.no Den norske legeforening Postboks 1152 Sentrum 0107 Oslo

Sjelden fører et bytte av en statsråd til så mye dynamikk som da helse- og omsorgsminister Sylvia Brustad i juni 2008 ble erstattet med Bjarne Håkon Hanssen. Fra et langvarig søkelys på finansiering og budsjettoverskridelser i spesialisthelsetjenesten, fikk man nærmest over natten et kraftig fokus på manglende samhandling. Den nye statsråden kunngjorde 24. september 2008 at regjeringen ville arbeide mot en ny stor helsereform, en samhandlingsreform. Statsråden formulerte det selv slik: «Hvilke økonomiske og juridiske systemer trengs for at rett samhandling skal skje på grunn av systemet og ikke på tross av systemet?» (1).

\section{Valgflesk eller virkelig vilje?}

Enkelte har hevdet at samhandlingsreformen bare er valgflesk (2). Det er imidlertid en gammel erkjennelse at en bære-

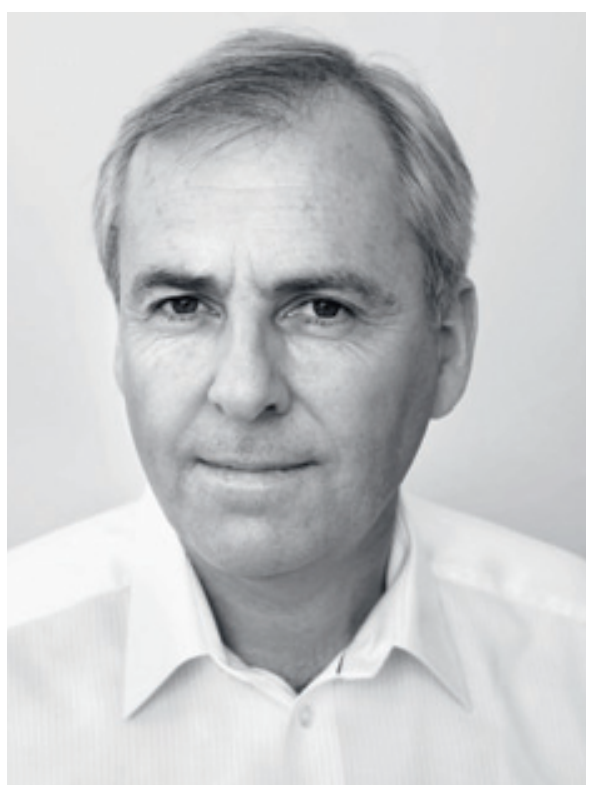

Jan Emil Kristoffersen, leder i Allmennlegeforeningen, stiller til valg. Foto Legeforeningen kraftig helsetjeneste krever en balansert utvikling mellom nivåene. Bakgrunnen for at arbeidet med en ny lov om helsetjenesten i kommunene ble startet i 1970-årene, var bl.a. rekrutteringssvikt til allmennlegetjenesten og et politisk ønske om etableringsog kostnadskontroll. I odelstingsproposisjon nr. 36 (1978-79) til forslaget om en midlertidig lov om regulering av legetjenester het det bl.a.:

«Komiteen vil peke på den betydelige ubalanse som utbyggingen av vårt helsei Lov om sykehus m.v. av 19. juni 1969 har det skjedd en hurtig utbygging av helsetjenesten i institusjon, mens distriktshelsetjenesten ikke har hatt en tilsvarende lov og er blitt hengende etter. - Mens antallet nye distriktslegestillinger økte med 20 pst. i tiden 1960-75, økte antallet sykehusleger i samme tidsrom med 130 pst.»

Etter at lov om helsetjenesten i kommunene trådte i kraft i 1984, kom det en viss økning av legeårsverk i kommunene. I tiden 1985-88 var denne økningen på godt og vel $10 \%$ (3). I ettertid må man kunne konstatere at intensjonene om å styrke legetjenesten i distriktene ved å gi kommunene et ansvar for organisering, ikke helt har slått til.

\section{Norge er ikke alene}

Internasjonalt er opprusting av primærhelsetjenesten et viktig tema for Verdens helseorganisasjon (WHO). I 2008 markerte de 30-årsjubileet for Alma-Ata- deklarasjonen (4) og ga i den forbindelse ut sin årlige helserapport med tittelen Primary health care - now more than ever (5). I rapporten påpekes det at en robust primærhelsetjeneste er en nødvendig del av en velfungerende helsetjeneste både $\mathrm{i}$ fattige og rike land. Det er i tråd med Helsedirektoratets rapport fra 2007, som beskrev utviklingsgapet mellom første- og annenlinjetjenesten her i landet (6).

Det er bred enighet om at fastlegeordningen er en helsepolitisk suksess, men de allmennmedisinske fagmiljøene har helt siden 2001 pekt på at fastlegeordningen var en administrativ reform som i neste omgang måtte følges opp med nødvendig utvikling vesen etter hvert har fått. Med bakgrunn av kapasitet og faglig utviklingsarbeid. Uansett må en robust spesialisthelsetjeneste ikke bare opprettholdes, men videreutvikles slik at en samlet helsetjeneste kan møte morgendagens utfordringer. Den økende fragmenteringen av spesialisthelsetjenesten skaper dessuten et voksende samhandlingsproblem i seg selv.

Vår britiske kollega Iona Heath har oppsummert primærhelsetjenestens utfordringer og rolle $\mathrm{i}$ en kommentarartikkel i $B M J$ i 2007: «Trust is built on strong personal relationships and on levels of skill and expertise. Patients must be able to trust that the doctor working at the first point of contact will recognise the early signs of serious and life-threatening disease. This can be achieved only by extensive and rigorous training, not by fragmentation of the first point of contact or by delegation to those with less training and less knowledge of the extent of diagnostic possibility» (7).

\section{Samhandling \\ krever kvalitetsledelse}

Samhandlingens potensial for økt kvalitet $i$ et pasientforløp er direkte avhengig av kvaliteten i arbeidet den enkelte aktør utfører. Hvis det ikke er kvalitet på mikronivået, vil styrket samhandling ikke utløse gevinstpotensialet.

Dette betyr at både fastleger, avtalespesialister og sykehusleger må settes i stand til å:

- Ha tid, rom og verktøy til å kommunisere med hverandre

- Gjøre mer av de riktige oppgavene

- Gjøre mindre av de unyttige oppgavene

- Ikke gjøre det som gjøres like bra og billigere hos den annen part

\section{Penger og paragrafer}

Et tydeligere aktøransvar er et nødvendig virkemiddel for at en samhandlingsreform skal bli nyttig. I prinsippet kan myndighetene bruke lov, forskrift, avtaler og økonomiske virkemidler som understøtter gode pasientforløp.

I samspillet mellom første- og annenlinjetjenesten er det i dag tatt i bruk få økonomiske virkemidler. I dag vil det f.eks. lønne seg for kommunene at innbyggere er innlagt i sykehus fremfor i kommunale sykehjem, og det kan lønne seg for helseforetakene å tilby behandling som heller burde ha skjedd i kommunehelsetjenesten.

Det er spennende og utfordrende at 
helse- og omsorgsministeren vurderer den ferske danske modellen der kommunene faktureres for en prosentandel av innbyggernes sykehusopphold og derved får et klart incentiv for å ruste opp det kommunale helsevesen (8).

\section{Styrk samhandling innad i tjenestenivåene}

I kommunesektoren er det påfallende liten grad av samordning og tilrettelegging for samhandling i lov- og forskriftsverket. Følgene av dette for barn og unge med psykiske helseplager beskrives av organisasjonen Voksne for Barn i et innspill til Helse- og omsorgsdepartementet i juni 2006: «Slik tilbudene framstår i dag, oppleves de fragmentariske, tilfeldige og uten systematisk koordinering. Det er ikke behovet man har, men hvilken instans man møter, som er avgjørende for hvilket tilbud som gis» (9).

Det er blitt stadig tydeligere at regjeringen orienterer seg mot en kommunal helsereform mer enn en samhandlingsreform i den bebudede stortingsmeldingen. Dette er neppe fordi man anser at samhandlingen internt $i$ annenlinjetjenesten er så god at det er lite å gripe fatt i, men er trolig et bevisst valgt fokus på styrking og koordinering $i$ en fragmentert kommunehelsetjeneste.

\section{Prioritering og lederansvar}

Et avklart prioriteringsperspektiv er en forutsetning for en vellykket samhandlingsreform. Dette vil kreve nytenkning både i helseforetakene og i kommunehelsetjenesten.

Spør man klinikere hva de skulle ønske seg mer av fra sine kolleger på det andre nivået, ønsker sykehuslegene mer kontakt med fastlegen som skal følge opp pasientene, og fastlegen ønsker mer kontakt med de kolleger som behandler hans eller hennes pasienter mens de er på sykehuset. Denne enkle bestillingen har ligget der i flere år enn det er hyggelig å tenke på.

Hvis legene ble mer tilgjengelige for hverandre på tvers av nivåene, ville mye vinnes. I sykehus betyr det at man må implementere en ordning med pasientansvarlig lege. Ingen ønsker seg et byråkratisk system for pasienter som ikke behøver annen koordinering enn den de allerede får, men for kompliserte forløp og for kronikere bør en forskrift om pasientansvarlig lege med høyere relevans enn dagens være et mål.

I dag er ca. $40 \%$ av legene i sykehusene i utdanningsstillinger, som i altfor stor grad er korte vikariater. Dette gir dårlige arbeidsvilkår og liten trygghet for disse legene. Samtidig taper helseforetakene på at man ikke har utdanningsleger som inngår i avdelingenes arbeid over tid og som på en helt annen måte ville kunne bidra til å skape merverdi ved tilgjengelighet og kontinuitet også i en situasjon der de ennå ikke arbeider selvstendig som spesialister. Det å ha en behandlerrelasjon til kronisk syke over tid gir en læringsverdi som utdanningsleger går glipp av i dag. Det er dårlig helseøkonomi på både kort og lang sikt.

I førstelinjetjenesten vil et prioriteringsperspektiv kreve at man spisser oppgavene. Utredning og behandling av sykdom, individrettet forebyggende helsearbeid og folkehelsearbeid må planlegges, organiseres og gjennomføres basert på kunnskap om hva som er nyttig, unyttig eller endog skadelig. Dette krever en kraftfull samfunnsog allmennmedisinsk kompetanse og ledelse i alle kommuner eller interkommunalt.

Det er legene som både i primær- og spesialisthelsetjenesten gjennomfører og har kompetanse til å gjennomføre utredning og behandling av sykdom. Hvis ikke legene får mulighet til å samhandle bedre enn i dag, kan nettoresultatet av en samhandlingsreform fort bli enda dyrere og mindre koordinerte tjenester.

En ukritisk oppbygging av nye og fragmenterte tjenester i kommunehelsetjenesten uten en effektiv fagledelse der god tilgjengelighet til medisinsk behandling av høy kvalitet har førsteprioritet, vil ikke tjene folkehelsen, men heller føre til enda sterkere press på spesialisthelsetjenesten.

\section{Litteratur}

1. Helse-og omsorgsdepartementet. Presentasjon av samhandlingsreformen (PDF) www.regjeringen. no/nb/dep/hod/kampanjer/samhandlingsreformen/presentasjon-av-samhandlingsreformenpdf.html?id=525190 (21.4.2009).

2. Mest valgflesk. Dagens næringsliv 20.4.2009.

3. St. meld. nr. 36 (1989-90) Røynsler med lova om helsetenesta i kommunane.

4. Declaration of Alma-Ata International Conference on Primary Health Care, Alma-Ata, USSR, 6-12 September 1978. www.who.int/hpr/NPH/docs/ declaration almaata.pdf (21.4.2009).

5. World Health Organization. The world health report 2008. Primary health care - now more than ever. www.who.int/whr/2008/en/index.html (21.4.2009).

6. Helsedirektoratet. Utviklingstrekk i helse- og sosialsektoren 2007. Rapport IS-1443. www. helsedirektoratet.no/publikasjoner/rapporter/ utviklingstrekk_i_helse_og_sosialsektoren_2007 72974 (21.4.2009).

7. Heath I. Only general practice can save the NHS. BMJ 2007; 335: 183.

8. Sundhetsvæsenet. www.sundhed.dk (21.4.2009)

9. Samhandling mellom kommunale helse- og omsorgstjenester/fastlegeordningen og spesialisthelsetjeneste - organisatorisk tiltak. Rapport. Oslo: Helse- og omsorgsdepartementet, 2006. www.regjeringen.no/nb/dep/hod/dok/ rapporter planer/rapporter/2006/Rapport---Samhandling-mellom-kommunale-helse--ogomsorgstjenesterfastlegeordningen-og-spesialisthelsetjenesten---organisatoriske-tiltak.html?id=106609 (21.4.2009).

Manuskriptet ble mottatt 21.4. 2009 og godkjent 23.4. 2009. Medisinsk redaktør Anne Kveim Lie. 